\title{
SOCIAL INNOVATION OF PT ADARO INDONESIA CSR LEADING PROGRAM "ISTANA MADU KALULUT" IN 2021
}

\author{
Aan Nurhadi ${ }^{1}$, Heriyanto Andilolo' ${ }^{1}$, Jatmiko Wicaksono ${ }^{1}$, Purnomo $^{2}$, Lenie Maelinae ${ }^{3}$, Rudi Fakhriadi ${ }^{3}$, Nita Pujianti ${ }^{3}$, \\ Noor Ahda Fadillah ${ }^{3}$, Laily Khairiyati ${ }^{3}$, Azmi Ma' ruf $^{3}$, Agung Waskito ${ }^{3}$, Anugrah Nur Rahmat ${ }^{3}$, Fakhriah $^{3}$, Hadrianti \\ H.D Lasari ${ }^{3}$, Sherly Theana ${ }^{3}$, Ammara Ulfa Azizah ${ }^{4}$, Deddy Hermawan ${ }^{4}$, Nashiruddin ${ }^{4}$, Fairuz Nur Fawaz ${ }^{4}$, Taufik $^{4}$, M. \\ Gilmani $^{4}$, Neneng Husanah ${ }^{4}$, Raudatul Jinan ${ }^{4}$, Winda Saukina $\mathrm{SJ}^{4}$, Noor Laila Afifah ${ }^{4}$, Riska Noor Azizah ${ }^{4}$, Rizkya \\ Amanda $^{4}$
}

\author{
${ }^{I}$ Corporate Social Responsibility PT Adaro Indonesia, Balangan \\ ${ }^{2}$ Social Investment Indonesia, Jakarta \\ ${ }^{3}$ Karya Kompas Konsultan, Samarinda \\ ${ }^{4}$ Faculty of Medicine, University of Lambung Mangkurat
}

DOI: 10.29322/IJSRP.11.11.2021.p11932

http://dx.doi.org/10.29322/IJSRP.11.11.2021.p11932

\begin{abstract}
The "Istana Kalulut" program is a form of community development carried out by PT Adaro Indonesia's CSR which began in 2018. The company seeks to change the mindset and behavior of the community with the Kalulut cultivation pattern which has succeeded in increasing the number of Kalulut bee farmers, decreasing the number of trees cut in the area. In the reclamation of the company, the community utilizes kalulut bee cultivation as a livelihood, becomes an education center for kalulut cultivation, and seeks to encourage the community to carry out cultivation in the form of developing kalulut honey which has been implemented in post-mining areas, so the duplication results can benefit the community in the company's operational areas through good competency transfer process. The program, which has become an environmental innovation and social innovation, was developed based on problems and based on community needs that are able to synergize with sustainable development and play a role in disasters, increase community capacities and capabilities, new roles and relationships in social life and develop local assets and human resources. The method used is in this study is social return on investment (SROI) analysis with primary data in the form of Indepht interviews and Focus Group Discussions conducted on 3 elements, that are representatives from companies, government and Civil Social Organizations (CSOs) and secondary data. Based on the calculation of the Social Return On Investment (SROI) ratio that has been carried out, it is known that for every 1 Rupiah invested in the Kalulut Palace (Istana Kalulut) program, there will be a social return on investment of 30.34 Rupiah. This ratio is classified as high or very promising in the world of impact investment. The payback period on investment is quite short where for an investment of IDR 524,935,000 it will take only 1.9 months before an equivalent value of the investment is realized.
\end{abstract}

Keywords: CSR, social return on investment, kalulut honey, Adaro Indonesia

\section{INTRODUCTION}

PT Adaro Indonesia is one of the government contractors in the context of coal exploitation, according to the First Generation Coal Mining Concession Contract of Work (PKP2B), No. J2/Ji.DU/52/82 November 16, 1982 (Soendjoto et al., 2016). The mining locations are in Tabalong Regency and Balangan Regency, South Kalimantan Province. Adaro's coal contains very low ash, sulfur and NOx, which is why it is known as "Envirocoal" coal (Hutapea et al., 2014; Soendjoto et al., 2015). Adaro's coal is marketed to meet domestic and international needs as raw material for Coal Steam Power Plants (Abdurahman et al., 2020).
The mining industry is obliged to implement community empowerment programs in order to provide benefits to the environment and socio-economic community around the mine. So in addition to carrying out production operations, coal companies also carry out corporate social responsibility activities or also known as Corporate Social Responsibility (CSR) by creating superior programs in the community based on resources owned by the region. This is carried out in order to provide positive feedback to the community around mining operations, which are directly or indirectly affected to increase independence and welfare in terms of environmental, economic, and social aspects.

Corporate Social Responsibilityis a basic need for 
ISSN 2250-3153

companies as part of interacting and adapting to the surrounding community. Since the beginning of its existence, the business community has believed that their main responsibility is to make profits for their investors (shareholders). Along with business activities that are in the midst of society with all its dynamics, there is awareness of the company to be involved in community life as a corporate social environment, namely through the implementation of Corporate Social Responsibility (CSR) which is increasing from time to time, not only because of the existence of corporate social responsibility. juridical demands in the presence of laws and regulations governing the implementation of CSR, but also because of the company's desire to participate in creating sustainable development through various CSR programs carried out by the company together with the surrounding community so that the company gets social benefits in the form of trust (trust) for community acceptance in implementing programs that are needed by the community in building self-reliance. (Kiptia et al., 2017).

Every program that is run is inteprreted as a form of social investment made by the company, so like an investment it must be measurable and is expected to bring benefits in the form of independence and welfare for the community. So each program needs to measure the financial value of the program's impact through the Social Return on Investment (SROI) method. One of the reasons companies conduct social reporting is for strategic reasons (Rusdin, 2016), so that companies are increasingly aware of the importance of implementing CSR programs as part of their social responsibility. of its business strategy. Because according to EIU (2015) in Rusdin (2016), the results of a study by the Economist Intelligence Unit show that $85 \%$ of senior executives and investors from various organizations make CSR the main consideration in decision making. The achievement value in social reporting obtained by the company as a form of information disclosure will assist the company in understanding and managing the program better, effectively and efficiently in the future. This will help companies to make more informed decisions on the choice of program type, strategy, budget, and scale of each program to be implemented. The assessment can also be used as a communication material for the company in a clearer and more consistent way to stakeholders. This can be data that will assist companies in managing risks, identifying opportunities, and increasing the value of program financing, so that companies will be able to develop potentials for improving performance, information systems, and providing better benefits to the community and also to other stakeholders. The implication of this is that more and more companies are disclosing corporate social responsibility (CSR) information in their annual reports. Likewise, the amount and type of CSR information disclosed by companies is increasing (Pang, 1982; Guthrie, 1982; Gray, 1990; Gray et al, 1993; Sayekti, 1994; Kroyan, 2006).

As a consequence of an investment, the logical This publication is licensed under Creative Commons Attribution CC BY. assessment of the investment returns is important. However, in practice, many companies have not carried out the assessment process for the social investments that have been made, especially in terms of indirect results (outcomes) and related to the resulting impacts, so the process of assessing the social impact of the investments that have been made is a challenge for them. company. Several conventional approaches are usually used to measure how much value a program can create. However, so far the approach used is still oriented towards the output of the program and not the impact it produces.

The "Istana Kalulut" program is a form of PT Adaro Indonesia's CSR community development which started in 2018. In this program, the company seeks to change the mindset and behavior of the community, which initially harvested honey by hunting and felling trees, turning to harvesting by cultivation. . The outputs of the program are based on the results of a review by Nurhayati, et al in 2020, namely; there is an increase in the number of Kalulut bee farmers, a decrease in the number of trees cut down in the PT Adaro Indonesia reclamation area, the community uses Kalulut bee cultivation as their livelihood, the Kalulut Palace becomes an education center for Kalulut cultivation, and seeks to encourage the community to cultivate and social innovation in the form of ways to develop kalulut honey that can be carried out post-mining so that the duplication results can be useful for the community (Nurhayati et al, 2020).

Based on PT Adaro Indonesia's Rapid Environmental Assessment on Disaster Study, the Istana Kalulut Program is one of the programs that PT Adaro Indonesia continues to foster in relation to disaster sensitivity for empowering small and medium enterprises (SMEs) in the company's operational areas with a focus on kalulut honey products that can be a supplement to support the prevention and control of Covid-19.

The Corporate Social Responsibility (CSR) program in the context of implementing sustainable development plays an important role. First, the CSR program shows the concern of the corporate or company to participate in thinking and developing the community both in terms of the social empowerment program and in terms of setting aside part of the company's profit funds that are intended for empowering programs. Second, the CSR program shows the company's participation in preserving the environment when exploiting and exploring natural resources so that the Kalulut Palace program supports SDGs Indicators, especially indicator 3, namely good health and welfare and indicator 8 Decent Work and Economic Growth and Indicator 15. Maintaining terrestrial ecosystems.

Based on the research of PT Adaro Indonesia's CSR team in 2020 and 2021, it is known that the output and success indicators of Kalulut honey bee cultivation are indicated by an increase in the number of honey bee nests to 300 nests, an increase in productivity from 7-10 liters/month to 30 liters/month, and product packaging. marketable, and increased revenue and marketing reach. From the quality 
aspect, the kalulut honey produced shows that all honey parameters meet the honey quality requirements according to the Indonesian National Standard (triwibowo, 2021, nurhayati 2020).

Based on research in the previous year, it is known that an orientation based solely on output will be less than optimal in seeing the value that can be created from a program, because essentially a program will be said to be successful if it can provide a positive change for the beneficiaries. This is what makes the assessment of impact oriented to outcome even more important, not just output. Therefore, the measurement of the outcome of the "Kalulut Palace" Program is measured through the Social Return on Investment (SROI) method. SROI will support the realization of sustainable development because each program will be measured for its effectiveness by referring to the impact generated after the program runs

\section{RESEARCH METHOD}

a. Social Inovation

1. Primary Data

Indepht interviews and Focus Group Discussions were conducted with 3 elements, namely representatives from companies, the government and Civil Social Organizations (CSOs) with the aim of obtaining qualitative data regarding the positive impact of the Kalulut Palace Program based on community needs, the program can solve community social problems, increase community capacity, creating new roles and relationships in social life, in developing community capacities, in providing environmental impacts, in providing economic impacts, in providing health impacts, in developing assets and human resources (HR) and in the sustainability of the Community Development Program.

2. Secondary Data

The data used is related to the Life Cycle Assessment (LCA), Eco Innovation Document, Rapid Environmental Assessment on Disaster (REAOD) document, community satisfaction index document and SDG's Indicator Document in the Metadata Summary of Indonesia's Sustainable Development Goals/SDGs.

b. Social Return on Investment

According to the SROI Network, SROI is "a framework based on social generally accepted accounting principles (SGAAP) that can be used to help manage and understand social, economic and environmental outcomes." c. Analysis type

1) Evaluative, carried out retrospectively and based on actual results that have occurred.

2) Forecast, predicts how much social value will be created if the activity fulfills the desired outcome.

d. Formulation

$[\mathrm{SROI}]=\frac{\text { Net Present Value of Bene fit }}{\text { Net Present Value of Investment }}$

d. Study parameters

This research was conducted with reference to the SROI measurement methods, principles, and guidelines initiated by The SROI Network UK. These phases are:

1. Define scope and identify stakeholders

2. Mapping the outcomes of each stakeholder

3. Establish indicators and values for each outcome

4. Impact fixation

5. Calculating SROI

6. SROI Reporting

e. Principles of Analysis

The principle of SROI analysis is as follows:

1. Engaging Stakeholders

2. Understand what changed

3. Give value (IDR) to what is important

4. Include only significant relevant changes

5. Don't claim changes are too different (deadweight, attribution, displacement, drop off)

6. Transparent

7. Verification of calculation results

In addition, you should also pay attention to:

1. Measuring the magnitude of the impact that is the result of the organization's activities to reduce the risk of overclaiming.

2. Impact $=$ (outcomes $)-($ deadweight, attribution, drop off, displacement)

3. Deadweight: any changes that will happen without you doing any intervention/activity or not.

4. Attribution: changes obtained from the intervention of other parties.

5. Drop off: calculate how much the effect of the activity will decrease over time.

6. Displacement: occurs when the benefits obtained are at the expense of others outside the program.

f. Data collection

g. Research respondents consist of:

1. Private company in the program area (PT Adaro Indonesia)

2. Local Government in Balangan Regency (DLH)

3. The CSO (Civil Society Organization) in the program area is implemented 


\section{FINDINGS}

\section{Social Return On Investment (SROI) Analysis}

Table 1. .Establishing Scope and Identifying Key Stakeholders

\begin{tabular}{|c|c|c|}
\hline & Stakeholders & Form of Role / Linkage \\
\hline \multicolumn{3}{|c|}{ Benefit recipients : } \\
\hline \multirow[t]{2}{*}{ Consumer } & Consumer & - $\quad$ Consuming honey for health \\
\hline & shop owner & - $\quad$ Add shop consumers \\
\hline Agent & Seller & $\begin{array}{ll}- & \text { Sell } \\
- & \text { Cultivating } \\
\text { - } & \text { Main source of income } \\
- & \text { Side job }\end{array}$ \\
\hline Manager & Cultivator & $\begin{array}{ll}- & \text { Cultivating } \\
- & \text { Supplying } \\
\text { - } & \text { Consuming } \\
\text { - } & \text { Train kalulut bee cultivation }\end{array}$ \\
\hline Non Consumer & Inhabitant & - $\quad$ Consuming honey \\
\hline & Training participants & - $\quad$ Kalulut honey cultivation training participants \\
\hline
\end{tabular}

Table 2. Input of Kalulut Honey Palace (Istana Madu Kalulut) Program

\begin{tabular}{|c|c|c|c|c|}
\hline No & 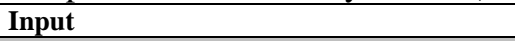 & Volume & Quantity & Information \\
\hline \multirow[t]{12}{*}{1} & \multicolumn{4}{|l|}{ Manager } \\
\hline & $\begin{array}{ll}\text { - } & \text { Land purchase } \\
\text { - } & \text { Vegetation } \\
\text { - } & \text { Tool } \\
\text { - } & \text { Infrastructure } \\
\text { - } & \text { Harvest tools } \\
\text { - } & \text { Honey pot } \\
\end{array}$ & 1 & IDR $130,935,000$ & $\begin{array}{l}\text { The initial capital for the construction of the Kalulut } \\
\text { Honey Palace }\end{array}$ \\
\hline & glass box & 1 & IDR. $16,000,000$ & Storage \\
\hline & chainsaw tool & 1 & IDR 200.000 & Tools used for cultivation \\
\hline & Gloves & 50 & IDR 500,000 & Standard for harvesting \\
\hline & Mask & 50 & IDR 150,000 & Standard for harvesting \\
\hline & Cultivation method book & 2 & IDR. 2,500,000 & Books about honey cultivation \\
\hline & Bottle & 1500 & IDR. $1,500,000$ & Packaging bottles, stickers and seals \\
\hline & Worker & 10 & IDR. $1,500,000$ & Helped workers at harvest \\
\hline & Pump & 1 & IDR. 350,000 & Pumps suck honey and postage \\
\hline & Seeds & 4000 & IDR. 200,000,000 & $\begin{array}{l}\text { Purchase of seeds of kulibit, tears of the bride and } \\
\text { groom }\end{array}$ \\
\hline & Sub-Total & & \multicolumn{2}{|l|}{ IDR 355.435.000 } \\
\hline 2 & \multicolumn{4}{|l|}{ Company } \\
\hline & - $\quad$ Development & 1 & IDR. $100,000,000$ & Development fund \\
\hline & \multirow{2}{*}{$\begin{array}{l}\text { - } \\
\text { - } \\
\text { Facilities and infrastructure (warehouse, } \\
\text { bridge, stairs, gajebo, batapress) } \\
\text { - } \quad \text { Giving seeds }\end{array}$} & \multirow[t]{2}{*}{1} & \multirow[t]{2}{*}{ IDR. $60,000,000$} & \multirow[t]{2}{*}{ Advanced development fund } \\
\hline & & & & \\
\hline & - $\quad$ PIRT & 1 & IDR. $3,500,000$ & PIRT permit creation \\
\hline & \multicolumn{2}{|l|}{ Sub-Total } & \multicolumn{2}{|l|}{ IDR 169,500,000 } \\
\hline \multicolumn{3}{|c|}{ TOTAL } & \multicolumn{2}{|l|}{ IDR 524,935,000 } \\
\hline
\end{tabular}

Table 3. Monetization technique, proxy value and outcome duration

\begin{tabular}{|c|c|c|c|c|c|c|}
\hline Indicator & $\begin{array}{c}\text { Duration } \\
\text { (years) }\end{array}$ & $\begin{array}{c}\text { Monetization } \\
\text { Techniques }\end{array}$ & Proxy & Source & Proxy value & Rationale \\
\hline \multirow[t]{3}{*}{ Health improvement } & \multirow[t]{3}{*}{1} & \multirow[t]{3}{*}{ Benefit unit cost } & $\begin{array}{l}\text { Hypertension } \\
\text { treatment costs }\end{array}$ & $\begin{array}{l}\text { Drug price list on } \\
\text { the Halodoc site }\end{array}$ & IDR. 72,000 & $\begin{array}{l}\text { The cost of treatment for } 1 \text { year } \\
\text { with a dose of } 1 \text { time a day times } \\
\text { the minimum price of the drug }\end{array}$ \\
\hline & & & $\begin{array}{l}\text { Gout treatment } \\
\text { costs }\end{array}$ & $\begin{array}{l}\text { Drug price list on } \\
\text { the Halodoc site }\end{array}$ & IDR. 260,000 & $\begin{array}{l}\text { Medical expenses for } 1 \text { year with } \\
\text { a dose of } 3 \text { times a day times the } \\
\text { minimum price of the drug }\end{array}$ \\
\hline & & & $\begin{array}{l}\text { Diabetes } \\
\text { mellitus } \\
\text { treatment costs }\end{array}$ & $\begin{array}{l}\text { In-depth } \\
\text { interview results }\end{array}$ & IDR. 364,000 & $\begin{array}{l}\text { The cost of treatment for } 1 \text { year } \\
\text { with a dose of } 3 \text { times a day or } 1 \\
\text { caplet } 3-7 \text { days times the } \\
\text { minimum price of the drug }\end{array}$ \\
\hline $\begin{array}{l}\text { Additional treatment } \\
\text { when sick }\end{array}$ & 1 & Benefit unit cost & $\begin{array}{l}\text { Medical } \\
\text { expenses to the } \\
\text { doctor }\end{array}$ & $\begin{array}{l}\text { In-depth } \\
\text { interview results }\end{array}$ & IDR 100,000 & $\begin{array}{l}\text { Costs incurred for treatment } 1 \\
\text { time to the doctor }\end{array}$ \\
\hline $\begin{array}{l}\text { Kalulut honey } \\
\text { cultivation training }\end{array}$ & 1 & Benefit unit cost & $\begin{array}{l}\text { Cost of training } \\
\text { for beekeeping } \\
\text { in kalulut }\end{array}$ & $\begin{array}{l}\text { Minimum } \\
\text { training fee } \\
\text { offered at some } \\
\text { cultivation } \\
\text { training sites }\end{array}$ & IDR 7,500,000 & $\begin{array}{l}\text { Training costs for } 10 \text { people } \\
\text { consisting of cultivation materials } \\
\text { and from honey management to } \\
\text { honey packaging }\end{array}$ \\
\hline
\end{tabular}




\begin{tabular}{|c|c|c|c|c|c|c|}
\hline Indicator & $\begin{array}{c}\text { Duration } \\
\text { (years) }\end{array}$ & $\begin{array}{c}\text { Monetization } \\
\text { Techniques }\end{array}$ & Proxy & Source & Proxy value & Rationale \\
\hline Manager income & 1 & Benefit unit cost & $\begin{array}{l}\text { Benefits for the } \\
\text { manager }\end{array}$ & $\begin{array}{l}\text { Results of in- } \\
\text { depth interviews } \\
\text { and financial } \\
\text { reports }\end{array}$ & $\begin{array}{r}\text { IDR. } \\
168,000,000\end{array}$ & $\begin{array}{l}\text { The average profit obtained is a } \\
\text { minimum of IDR. } 350,000 \text { (not } \\
\text { full vegetation) for } 1 \text { year }\end{array}$ \\
\hline Agent income & 1 & Benefit unit cost & $\begin{array}{l}\text { The benefits of } \\
\text { the agent }\end{array}$ & $\begin{array}{l}\text { In-depth } \\
\text { interview results }\end{array}$ & IDR. 4,200,000 & $\begin{array}{l}\text { Net profit from selling Kalulut } \\
\text { honey }\end{array}$ \\
\hline Less tree felling & 2 & Benefit unit cost & $\begin{array}{l}\text { Reduced losses } \\
\text { for each tree } \\
\text { felling }\end{array}$ & $\begin{array}{l}\text { Based on } \\
\text { scientific } \\
\text { publications that } \\
\text { the loss of cutting } \\
1 \text { tree trunk is } \\
\text { converted } \\
\text { IDR800,000 }\end{array}$ & $\begin{array}{r}\text { IDR } \\
800,000,000\end{array}$ & $\begin{array}{l}\text { Conversion of losses caused by } 1 \\
\text { tree that is cut multiplied by an } \\
\text { average of } 1000 \text { stems/year }\end{array}$ \\
\hline $\begin{array}{l}\text { The development of } \\
\text { the Kalulut colony is } \\
350 \text { colonies }\end{array}$ & 1 & Benefit unit cost & $\begin{array}{l}\text { Cultivated } \\
\text { income }\end{array}$ & $\begin{array}{l}\text { In-depth } \\
\text { interview results }\end{array}$ & $\begin{array}{r}\text { IDR. } \\
122,500,000\end{array}$ & $\begin{array}{l}\text { The value of the benefits of the } \\
\text { Kalulut honey bee is } 350,000 \text { per } \\
\text { colony/lok }\end{array}$ \\
\hline $\begin{array}{l}\text { Awakening } 4 \text { species } \\
\text { (Itama, Torasica, } \\
\text { Terminata, Leavicep) }\end{array}$ & 1 & Benefit unit cost & $\begin{array}{l}\text { Income obtained } \\
\text { from } 4 \text { species } \\
\text { of bees }\end{array}$ & $\begin{array}{l}\text { Prices of bee } \\
\text { colonies of each } \\
\text { species on the } \\
\text { market and } \\
\text { Scientific } \\
\text { Publications on } \\
\text { Comparative } \\
\text { Studies of Bees, } \\
\text { in-depth } \\
\text { interview }\end{array}$ & $\begin{array}{r}\text { IDR. } \\
81,275,000\end{array}$ & $\begin{array}{l}\text { - Itama: } 140,000 \times 260= \\
\text { 36,400,000 } \\
\text { - Thoracic: } 850,000 \times 40= \\
\text { 34,000,000 } \\
\text { minate: } 200,000 \times 25=5,000,000 \\
\text { avicep: } 235,000 \times 25=5.875,000\end{array}$ \\
\hline $\begin{array}{l}33 \text { types of plant } \\
\text { variants }\end{array}$ & 1 & Benefit unit cost & $\begin{array}{l}\text { Income earned } \\
\text { from } 33 \text { types of } \\
\text { plant variants }\end{array}$ & $\begin{array}{l}\text { Prices of plant } \\
\text { variants that } \\
\text { apply in the } \\
\text { market }\end{array}$ & $\begin{array}{r}\text { IDR. } \\
11,800,000\end{array}$ & 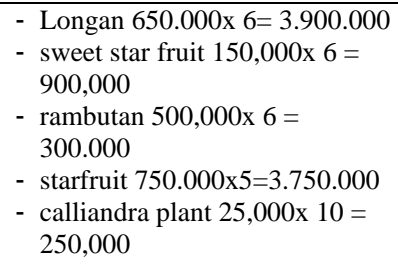 \\
\hline $\begin{array}{l}\text { Distribution of seeds } \\
\text { to Kalulut farmers in } \\
\text { Balangan }\end{array}$ & 1 & Benefit unit cost & $\begin{array}{l}\text { Income from } \\
\text { seeds received } \\
\text { by } 32 \text { farmers }\end{array}$ & $\begin{array}{l}\text { The price of seeds } \\
\text { that apply in the } \\
\text { market }\end{array}$ & $\begin{array}{r}\text { IDR. } \\
24,000,000\end{array}$ & $\begin{array}{l}32 \text { people @ } 30 \text { seeds x IDR. } \\
25,000=\text { IDR. 24,000,000 }\end{array}$ \\
\hline $\begin{array}{l}\text { Increase in Income } \\
\text { from IDR } 4 \text { Million to } \\
\text { IDR } 6 \text { Million/month }\end{array}$ & 1 & Benefit unit cost & $\begin{array}{l}\text { Increased } \\
\text { monthly income } \\
\text { of Kalulut honey }\end{array}$ & $\begin{array}{l}\text { Financial } \\
\text { statements }\end{array}$ & $\begin{array}{r}\text { IDR. } \\
48,000,000\end{array}$ & $\begin{array}{l}\text { 2018-2019 Revenue: @ IDR. } \\
4000.000 x 24 \text { months = IDR. } \\
96,000,000 \\
\text { Income for the Year 2020-2021: } \\
\text { @ IDR. 600.000x24 months = } \\
\text { IDR. 144,000,000 }\end{array}$ \\
\hline $\begin{array}{l}32 \text { people changed } \\
\text { their behavior from } \\
\text { hunters to cultivators }\end{array}$ & 1 & Benefit unit cost & $\begin{array}{l}\text { The results } \\
\text { obtained from } \\
\text { honey } \\
\text { cultivation }\end{array}$ & $\begin{array}{l}\text { In-depth } \\
\text { interview results }\end{array}$ & $\begin{array}{r}\text { IDR. } \\
672,000,000\end{array}$ & $\begin{array}{l}5 \text { liters @ IDR. 350,000 x } 32 \\
\text { people x } 12 \text { months }\end{array}$ \\
\hline $\begin{array}{l}32 \text { people know how } \\
\text { to take care of Kalulut }\end{array}$ & 1 & Benefit unit cost & $\begin{array}{l}\text { The results } \\
\text { obtained from } \\
\text { how to maintain } \\
\text { the right honey }\end{array}$ & $\begin{array}{l}\text { In-depth } \\
\text { interview results }\end{array}$ & $\begin{array}{r}\text { IDR. } \\
672,000,000\end{array}$ & $\begin{array}{l}32 \text { people x } 5 \text { liters x IDR } \\
350,000 \times 12 \text { months }\end{array}$ \\
\hline $\begin{array}{l}32 \text { people plant } \\
\text { flowers }\end{array}$ & 1 & Benefit unit cost & $\begin{array}{l}\text { The results } \\
\text { obtained from } \\
\text { planting flower } \\
\text { plants }\end{array}$ & $\begin{array}{l}\text { In-depth } \\
\text { interview results }\end{array}$ & $\begin{array}{r}\text { IDR. } \\
672,000,000\end{array}$ & $\begin{array}{l}\text { The results obtained from } \\
\text { planting flower plants by } 32 \\
\text { people with a minimum of } 5 \\
\text { liters of honey yield and sales of } \\
\text { IDR. } 350,000 \text { times } 12 \text { months }\end{array}$ \\
\hline $\begin{array}{l}\text { Duplication and } \\
\text { education of kalulut } \\
\text { cultivation in } 8 \\
\text { villages of ring } 1 \text { as } \\
\text { many as } 12 \text { people and } \\
\text { outside ring } 1 \text { in } 12 \\
\text { villages as many as } 20 \\
\text { people }\end{array}$ & 1 & Benefit unit cost & $\begin{array}{l}\text { Cost of } \\
\text { attending } \\
\text { education }\end{array}$ & $\begin{array}{l}\text { Minimum fees } \\
\text { offered in some } \\
\text { cultivation sites }\end{array}$ & IDR. $6,400,000$ & $\begin{array}{l}\text { Costs incurred for education per } \\
3 \text { months for } 1 \text { year }\end{array}$ \\
\hline $\begin{array}{l}\text { Scientific Publication } \\
\text { of the PRIMA } \\
\text { National Journal } \\
\text { "Development of } \\
\text { Kalulut Paringin } \\
\text { Balangan Honey: } \\
\text { Integration of the Coal } \\
\text { Post-Tanging Program } \\
\text { and Community } \\
\text { Empowerment. }\end{array}$ & 1 & Benefit unit cost & $\begin{array}{l}\text { Income earned } \\
\text { after scientific } \\
\text { publications }\end{array}$ & $\begin{array}{l}\text { Financial } \\
\text { statements }\end{array}$ & IDR. 1.583.000 & $\begin{array}{l}\text { The difference in income in } 2020 \\
\text { and } 2021\end{array}$ \\
\hline
\end{tabular}




\begin{tabular}{|c|c|c|c|c|c|c|}
\hline Indicator & $\begin{array}{c}\text { Duration } \\
\text { (years) }\end{array}$ & $\begin{array}{c}\text { Monetization } \\
\text { Techniques }\end{array}$ & Proxy & Source & Proxy value & Rationale \\
\hline $\begin{array}{l}\text { Establishment of a } \\
\text { network community } \\
\text { among Kalulut honey } \\
\text { farmers across } \\
\text { districts, namely } \\
\text { KOMPAK - Kalulut } \\
\text { Kalimantan } \\
\text { Beekeeping } \\
\text { Community - Zone } 2 \\
\text { which includes } \\
\text { Balangan, Tabalong, } \\
\text { Hulu Sungai Utara, } \\
\text { Hulu Sungai Tengah } \\
\text { regencies with a total } \\
\text { of } 80 \text { members. }\end{array}$ & 2 & Benefit unit cost & $\begin{array}{l}\text { Cost saving } \\
\text { from activities in } \\
\text { the community }\end{array}$ & $\begin{array}{l}\text { The value of self- } \\
\text { development } \\
\text { gained by the } \\
\text { presence of a } \\
\text { community }\end{array}$ & IDR. $6,400,000$ & $\begin{array}{l}\text { Conversion of expenses incurred } \\
\text { for personal development costs } \\
\text { per } 3 \text { months for } 1 \text { year }\end{array}$ \\
\hline
\end{tabular}

Table 4. Calculation of the Impact of the Kalulut Honey Palace (Istana Madu Kalulut) Program Based on Nature (environment)

\begin{tabular}{|l|c|c|l|l|}
\hline \multicolumn{1}{|c|}{ Indicator } & Duration (years) & Proxy value (IDR) & \multicolumn{1}{c|}{ Quantity } & \multicolumn{1}{c|}{ Total Impact Value (IDR) } \\
\hline Less tree felling IDR. 1,600,000,000 & IDR. 122,500,000 \\
\hline $\begin{array}{l}\text { The development of the Kalulut colony is 350 } \\
\text { colonies }\end{array}$ & 2 & IDR. 800,000,000 & 2000 & IDR. 81,275,000 \\
\hline $\begin{array}{l}\text { Awakening 4 species (Itama, Torasica, } \\
\text { Terminata, Leavicep) }\end{array}$ & 1 & IDR. 122,500,000 & 1 & \\
\hline 33 types of plant variants & 1 & IDR. 81,275,000 & 1 & IDR. 11,800,000 \\
\hline $\begin{array}{l}\text { Distribution of seeds to Kalulut farmers in } \\
\text { Balangan }\end{array}$ & 1 & IDR. 24,000,000 & 1 & IDR. 24,000,000 \\
\hline
\end{tabular}

Table 5. Calculation of the Impact of the Kalulut Honey Palace (Istana Madu Kalulut) by Economic (Economic)

\begin{tabular}{|l|c|l|c|l|}
\hline \multicolumn{1}{|c|}{ Indicator } & Duration (years) & \multicolumn{1}{|c|}{ Proxy value (IDR) } & Quantity & \multicolumn{1}{c|}{ Total Impact Value (IDR) } \\
\hline Manager income & 1 & IDR. 168,000,000 & 1 & IDR. 168,000,000 \\
\hline Agent income & 1 & IDR. 4,200,000 & 1 & IDR. 4,200,000 \\
\hline $\begin{array}{l}\text { Increase in Income from IDR 4 Million to IDR 6 } \\
\text { Million/month }\end{array}$ & 1 & IDR. 48,000,000 & 1 & IDR. 48,000,000 \\
\hline
\end{tabular}

Table 6. Calculation of the Impact of Kalulut Honey Palace (Istana Madu Kalulut) based on Wellbeing

\begin{tabular}{|l|c|l|l|l|}
\hline \multicolumn{1}{|c|}{ Indicator } & Duration (years) & \multicolumn{1}{|c|}{ Proxy value (IDR) } & Quantity & \multicolumn{1}{c|}{ Total Impact Value (IDR) } \\
\hline Health improvement & 1 & IDR. 72,000 & 1 & IDR. 72,000 \\
\hline Health improvement & 1 & IDR. 260,000 & 1 & IDR. 260,000 \\
\hline Health improvement & 1 & IDR. 364,000 & 1 & IDR. 364,000 \\
\hline Additional treatment when sick & 1 & IDR 100,000 & 1 & IDR 100,000 \\
\hline Kalulut honey cultivation training & 1 & IDR 7,500,000 & 1 & IDR 7,500,000 \\
\hline $\begin{array}{l}32 \text { people changed their behavior from hunters } \\
\text { to cultivators }\end{array}$ & 1 & IDR. 672,000,000 & 1 & IDR. 672,000,000 \\
\hline 32 people know how to take care of Kalulut & 1 & IDR. 672,000,000 & 1 & IDR. 672,000,000 \\
\hline 32 people plant flowers & 1 & IDR. 672,000,000 & 1 & IDR. 672,000,000 \\
\hline
\end{tabular}

Table 7. Calculation of the Impact of the Kalulut Honey Palace (Istana Madu Kalulut) based on Social

\begin{tabular}{|l|c|c|c|c|}
\hline \multicolumn{1}{|c|}{ Indicator } & Duration (years) & Proxy value (IDR) & Quantity & Total Impact Value (IDR) \\
\hline $\begin{array}{l}\text { Duplication and education of kalulut cultivation } \\
\text { in } 8 \text { villages of ring 1 as many as 12 people and } \\
\text { outside ring 1 in 12 villages as many as 20 } \\
\text { people }\end{array}$ & 1 & IDR. 6,400,000 & 1 & IDR. 6,400,000 \\
\hline $\begin{array}{l}\text { Scientific Publication of the PRIMA National } \\
\text { Journal "Development of Kalulut Paringin } \\
\text { Balangan Honey: Integration of the Coal Post- } \\
\text { Tanging Program and Community }\end{array}$ & & & & \\
Empowerment. & & IDR. 1.583.000 & 1 & IDR. 1.583.000 \\
\hline $\begin{array}{l}\text { Establishment of a network community among } \\
\text { Kalulut honey farmers across districts, namely } \\
\text { KOMPAK - Kalulut Kalimantan Beekeeping } \\
\text { Community - Zone 2 which includes Balangan, } \\
\text { Tabalong, Hulu Sungai Utara, Hulu Sungai } \\
\text { Tengah regencies with a total of 80 members. }\end{array}$ & & & & \\
\hline
\end{tabular}

Table 8. Total Impact Calculation 


\begin{tabular}{|l|l|l|l|l|}
\hline & Impact of nature & Economic impact & Wellbeing Impact & Social Impact \\
\hline Total & IDR. 1,039,575,000 & IDR. 220,200,000 & IDR. 2,016,803,500 & IDR. 14,383,000 \\
\hline
\end{tabular}

Table 9. Projected Impact Value for the next 5 years

\begin{tabular}{|c|c|c|c|c|c|}
\hline \multirow{2}{*}{ Program } & \multicolumn{5}{|c|}{ Total Impact Value } \\
\hline & Year 1 & Year 2 & Year 3 & Year 4 & Year 5 \\
\hline Nature's Impact & IDR. $1,039,575,000$ & IDR. $1,039,575,000$ & IDR. 1,039,575,000 & IDR. 1,039,575,000 & IDR. $1,039,575,000$ \\
\hline Economic Impact & IDR. 220,200,000 & IDR. 220,200,000 & IDR. 220,200,000 & IDR. 220,200,000 & IDR. 220,200,000 \\
\hline Wellbeing Impact & IDR. $2,016,803,500$ & IDR. 2,016,803,500 & IDR. 2,016,803,500 & IDR. $2,016,803,500$ & IDR. 2,016,803,500 \\
\hline Social Impact & IDR. 14,383,000 & IDR. 14,383,000 & IDR. 14,383,000 & IDR. 14,383,000 & IDR. 14,383,000 \\
\hline Total & IDR. 3,290,961,500 & IDR. 3,290,961,500 & IDR. 3,290,961,500 & IDR. 3,290,961,500 & IDR. 3,290,961,500 \\
\hline
\end{tabular}

Table 10. Net Present Value

\begin{tabular}{|c|c|c|c|c|c|c|}
\hline \multirow[t]{2}{*}{ Program } & \multicolumn{5}{|c|}{ Total Impact Value } & \multirow{2}{*}{$\begin{array}{c}\text { Total Present Value } \\
\text { (PV) }\end{array}$} \\
\hline & Year 1 & Year 2 & Year 3 & Year 4 & Year 5 & \\
\hline Nature's Impact & IDR. 1,039,575,000 & IDR. $1,039,575,000$ & IDR. 1,039,575,000 & IDR. 1,039,575,000 & IDR. 1,039,575,000 & IDR. 5,197,875,000 \\
\hline Economic Impact & IDR. 220,200,000 & IDR. 220,200,000 & IDR. 220,200,000 & IDR. 220,200,000 & IDR. 220,200,000 & IDR. 1.101.000 \\
\hline Wellbeing Impact & IDR. 2,016,803,500 & IDR. 2,016,803,500 & IDR. 2,016,803,500 & IDR. 2,016,803,500 & IDR. 2,016,803,500 & IDR. 10,084,017,500 \\
\hline Social Impact & IDR. $14,383,000$ & IDR. $14,383,000$ & IDR. 14,383,000 & IDR. 14,383,000 & IDR. $14,383,000$ & IDR. $71,915,000$ \\
\hline Total & IDR. 3,290,961,500 & IDR. 3,290,961,500 & IDR. 3,290,961,500 & IDR. 3,290,961,500 & IDR. 3,290,961,500 & IDR. $16,454,807,500$ \\
\hline \multicolumn{6}{|c|}{ Net present value $($ NPV) $=$ Total Present Value - Input (IDR 524,935,000) } & IDR $15,929,872,500$ \\
\hline
\end{tabular}

\section{Calculation of Return on Investment Ratio}

SROI Ratio $=\frac{N P V}{\text { Nilai Input }}=\frac{\text { IDR } 15929872500}{\text { IDR 524.935.000 }}$

SROI Ratio $=30.34: 1$

Based on the calculation of the SROI ratio, it is known that for every 1 Rupiah invested in the Kalulut Honey Palace (Istana Madu Kalulut) program, there will be a social return on investment of 30.34 Rupiah. This ratio is classified as high or very promising in the world of impact investment.

\section{Calculation of payback period}

$$
\begin{aligned}
& \text { Payback period }=\frac{\text { Nilai input }}{\text { PV:12 bulan }}=1.9 \\
& \text { months } \frac{\text { IDR } 524.935 .000}{\text { IDR3.290.961.500:12 bulan }}
\end{aligned}
$$

Based on the calculation of the payback period above, it is known that the payback period is quite short. Where these results indicate that for an investment of this size, it will only take 1.9 months before an equivalent value of the investment is realized.IDR 524.935.000.

\section{DISCUSSION}

\section{Program Link with Mine Closure, Core Competency \& Life Cycle Assessment}

The Community Development and Empowerment Program (PPM) named "UKM Mitra Kalulut Palace" which is located in ring 1 of the Paringin Mining Post-Mining Demonstration Area, Balangan Regency and makes it an Environmental Innovation Program (Eco Innovation) and Corporate Social Innovation by:

a. The change in the cultivation of Kalulut honey from a direct harvesting pattern by cutting down trees that become Kalulut's nests to sustainable cultivation with artificial nests. This is done by socializing the mentoring and training program for kalulut honey cultivation by involving partner SMEs in analyzing problems and preparing programs that will be run together. b. Intensive training on kalulut honey bee cultivation. This training aims to increase the production of Kalulut honey by increasing the Kalulut bee colony. This training is carried out through artificial nest propagation by breaking up and transferring bee colonies from natural nests in forest tree trunks to artificial nests made of used pallet wood. Prior to relocating the natural nest of Kalulut honey, technical guidance was carried out for the manufacture of artificial nests using used pallets from PT Adaro Indonesia. Cultivation training is also carried out by multiplying nests and multiplying types of vegetation that have the potential to be a source of food for the Kalulut honey bee.

c. Improving the quality of Kalulut honey products. The CSR team fosters the production process with Good Manufacturing Practice (GMP) by improving the honey harvesting process with an automatic suction machine, assisting in food eligibility licensing (PIRT) from the Health Office, attractive packaging designs, assistance in laboratory tests to determine the quality of the kalulut honey produced. , and marketable packaging. The indicator of the success of this activity is the results of laboratory tests according to the Indonesian National Standard (SNI) products.

\section{Community Satisfaction}

The Kalulut Palace program which has been implemented since 2018 has made the community satisfied, seen from the Community Satisfaction Index data in 2019 reaching $82.55 \%$ in the satisfied category. Overall indicators, when compared to 2018 remain in the satisfied category, but in value increased by 0.1 . In the environmental sector, IKM in 2019 was in the satisfied category of $81.90 \%$. This is an increase from 2018 of $1.90 \%$.

\section{Program Links with Disaster Sensitivity}


ISSN 2250-3153

Based on the Rapid Environmental Assessment On Disaster (REA) document, PT Adaro Indonesia identified and analyzed the company's role in the Kalulut Palace program so that this program can continue to survive during the Covid-19 pandemic. The company provides guidance to SMEs around the company's operational areas by ordering large quantities of products which are then distributed to the people in the operational areas as supplements and endurance in order to minimize transmission from Covid-19. Considering that honey products are rich in nutrients needed by the body to maintain and increase people's immunity. This includes the children of Pondok Pesantren Inan Village, South Paringin District where the need for kalulut honey reaches 1.5 liters per month for 46 children in Islamic boarding schools (pesantren).

\section{Program Analysis of SDG's}

The Corporate Social Responsibility (CSR) program in the context of implementing sustainable development plays an important role. First, the CSR program shows the concern of the corporate or company to participate in thinking and developing the community, both in terms of the social empowerment program and in terms of setting aside part of the company's profit funds that are intended for empowering programs. Second, the CSR program shows the company's participation in preserving the environment when exploiting and exploring natural resources.

The Kalulut Palace Program supports SDGs Indicators, especially indicator 3, namely good health and welfare and indicator 8 Decent Work and Economic Growth and Indicator 15. Maintaining terrestrial ecosystems

The relationship between the Kalulut Palace program and the SDGs is Indicator 3. Good health and well-being are:

1. Reducing the risk of infectious and non-infectious diseases such as Covid-19, hypertension, gout and others

2. Because now it is difficult to distinguish real and fake honey, kalulut honey which has been proven to be excellent because it is considered genuine and can increase stamina compared to ordinary honey.

3. changes in people's behavior from hunters to cultivators, understanding how to maintain kalulut and planting flower plants.

The relationship between the Kalulut Palace program and the SDGs is Indicator 8. Decent Work and Economic Growth:

1. With the honey kalulut business, the manager is able to meet primary (daily needs), secondary (education, electronics, land) and tertiary needs (going for hajj, umrah, tourism).

2. Provide an economic impact for the surrounding community with many guests who come to visit so as to increase the income of the surrounding community

3. Increase income for resellers who work together to sell kalulut honey for areas outside the district. Balangan, East Kalimantan
4. Adding employment opportunities for the surrounding community as workers who take honey and clean the environment around the Kalulut Palace, thereby creating a sense of togetherness and ownership related to the program

The relationship between the Kalulut Palace program and the SDGs is Indicator 15. Maintaining terrestrial ecosystems

1. Improving the environmental quality of water, air, soil by reducing the number of tree cuttings to get kalulut honey in the forest

2. Protected species of honey bee kalulut in the 4 main species in the environment

3. Protecting plant varieties as a food source from kalulut honey bees

4. With the presence of kalulut honey bees, there is a mutualism symbiosis in improving the environment, such as flowers that are sucked in by bees and will produce new flowers by natural pollination.

\section{The Positive Impact of the Kalulut Palace (Istana Kalulut) Program}

\section{1) Programs are developed based on community needs}

Based on the conclusions from the results of in-depth interviews and FGDs conducted with managers, community leaders and community beneficiaries, they are:

a. That the honey kalulut palace program has a lot of potential for kalulut bees that have economic value for cultivation and easier management methods

b. To serve as a profitable private business area in improving the community's economy

c. Kalulut honey has many benefits but not many people use it

d. Maintaining natural wealth in the Balangan area

e. To reduce tree cutting in land clearing

\section{a) PT Adaro Indonesia}

Based on the results of interviews with companies implementing CSR programs, it can be concluded:

- Community needs related to the Kalulut Palace program because initially the development of the kalulut honeycomb was not so widespread that many honey seekers did logging to get kalulut honey, with the development of kalulut honey, logging reduced

- Increase people's income with kalulut honey bee farming compared to other jobs

- The need to duplicate activities such as the Kalulut Palace to be developed in other Ring 1 villages

- As a research and development facility for the Kalulut Palace, QHSE (Quality Health Safe Environment) has been carried out for the post-mining area in the Paringin area by using artificial wood as a substitute for real wood.

- With the existence of the Kalulut Palace, the community's need for self-development has increased by developing 
ISSN 2250-3153

varieties of flower plants which are food for kalulut bees and the fruit can be used as medicine and full of nutrition, such as the development of planting crystal guavas carried out by the manager of the Kalulut Palace as many as 100 plants placed behind the development. honey kalulut in 2021

- With the existence of the Kalulut Palace, the community needs a pattern of independent cooperation between communities to increase knowledge, skills and the economy and conduct joint development research to improve the quality and quantity of honey.

\section{b) Department of Environment (DLH)}

Based on the results of interviews with the local government represented by the Department of Environment (DLH) of Balangan Regency, it was concluded that he did not know clearly whether this program was based on the social needs of the community or not, but he appreciated this CSR program because it is environmentally beneficial.

\section{c) Civil Social Organization (CSO) Manager}

Mr. Maskuni is a local hero who is the main originator and manager of kalulut honey cultivation. At first Mr. Maskuni and his colleagues were interested in cultivating natural resources in the paringin area, namely the kalulut bee (Trigona Thorasica and Trigona Itama). The existence of a shift in land use in the area makes managers interested in cultivating kalulut bees (Trigona Thorasica and Trigona Itama) which have economic value if managed and bred properly. At first, the local community was not interested in honey from kalulut bees found from nearby trees because it had a sour taste, unlike the taste of honey in general.

Honey from kalulut bees (Trigona Thorasica and Trigona Itama) found by the community is considered useless and not worth selling because of its sour taste. Therefore, people are less interested in cultivating honey from kalulut bees (Trigona Thorasica and Trigona Itama). Meanwhile, managers who are interested in finding information and the efficacy of the kalulut honey. It was found that the kalulut bee in the area when cultivated could be a source of income for the community in the future and can have good quality if processed in the right way.

\section{Community Leader}

According to a community leader in Paringin Kota Village, he knew that before the formation of the Kalulut Palace, Mr. Maskuni as the manager of the Kalulut Palace collaborated with one of the people in the area to cultivate kalulut bees and initially only had a small land of about $10 \mathrm{~m}^{2}$.

\section{Consumer}

Meanwhile, according to consumers in Paringin Kota Village, they know that the reason for the formation of the Kalulut Palace is because it cooperates with PT. Adaro Indonesia

The results of the Focus Group Discussion (FGD), the reason for the formation of the honey kalulut palace, was that the manager realized that kalulut honey had many benefits but the public was not interested. Because of this, the manager of the Kalulut Honey Palace (Istana Madu Kalulut)took the initiative to cultivate kalulut bees because he wanted to preserve the natural wealth in the area.

\section{2) Programs can solve community social problems}

Based on the conclusions from the results of in-depth interviews and FGDs conducted with managers, community leaders and community beneficiaries, they are:

a. Reducing illegal logging due to taking logs of kalulut bees from trees growing in the forest, including in the company's post-mining areas.

b. There is Kalulut Palace product branding for product adjustments and price increases

c. There is a breakdown of the kalulut bee colony and for the increase in vegetation as food for the kalulut bee

d. Increasing the bee community because from the beginning, honey hunters have decreased from 48 hunters to cultivators where 32 of them are fostered by the company

e. The technical change in taking honey from previously cutting down trees for cultivation has changed to a better and more sustainable place for cultivation.

f. Increased economy around the Kalulut Palace area because guests who come can buy food/drinks at stalls around the Kalulut Palace management area

g. With the Kalulut Palace, people no longer cut down trees carelessly

\section{a) PT Adaro Indonesia}

1. Reducing the gap from cultural views between managers to achieve the common goal of making kalulut honey as an economic source

2. Another social problem that can be handled is changing the perspective on the management of kalulut honey from forest to independent so that it does not damage the surrounding environment.

3. With the existence of the Kalulut Palace, the increase in cooperation between communities increases to form a new community in the management of Kalulut honey which is assisted in its development by the Kalulut Palace.

4. With the kalulut honey business, managers are able to meet primary, secondary and tertiary needs

5. With the existence of honey kalulut environmental programs can run so as to help stakeholders in environmental management 
6. The diversity of bees is maintained by the presence of diverse vegetation and can be protected from destruction

7. With the existence of the Kalulut Palace, the manager is able to carry out self-development by purchasing land for the previously closed entrance and for the addition of plant vegetation to increase the quality and quantity of honey.

\section{b) Department of Environment (DLH)}

Based on an interview with DLH Balangan, it was found that the Kalulut Palace CSR program overcomes social problems of the community, especially for the manager of the Kalulut honey.

\section{c) Civil Social Organization}

\section{Manager}

The results of an in-depth interview with the manager of the Madu Kalulut Palace, namely with the existence of the Kalulut Honey Palace, there is a social transition from wild kalulut honey hunters to cultivators. Increased knowledge of honey hunters, has a positive impact on their economy. Honey hunters can become businessmen by selling quality kalulut honey to immigrant communities. The existence of honey hunting, has a negative impact on the environment. The community generally still harvests the Kalulut Bees in the conventional way, namely by cutting down trees in the forest, including the reclamation area of PT Adaro Indonesia. Based on the results of in-depth interviews in 2021, it was found that there was an increase in the number of cultivators in 2019, where at that time there were 48 cultivators of which 32 were from honey hunters.

\section{Community Leader}

According to the results of in-depth interviews with community leaders, it was found that there was a change in the work of the people in Paringin Kota Village, namely those who initially worked as rubber farmers where rubber prices were very dynamic, now they are kalulut bee cultivators whose prices tend to be stable.

\section{Consumer}

The results of in-depth interviews with consumers showed that there was a social change with the existence of the Madu Kalulut Palace, namely the stalls around the Kalulut Madu Palace getting sales profits from the guests of the Madu Kalulut Palace who bought drinks at their stalls.

Based on the results of discussions with respondents during the Forum Group Discussion (FGD), it was said that with the existence of the Madu Kalulut Palace, people rarely cut down trees carelessly because it was difficult to find kalulut bee nests in the forest. In addition, the results of the FGD revealed that now the group members from the Madu Kalulut Palace are also experiencing a reduction because the kalulut bee nests belonging to the Kalulut Madu Palace group are not producing enough so that the nests are sold.

3) Community Development Program increases This publication is licensed under Creative Commons Attribution CC BY. http://dx.doi.org/10.29322/IJSRP.11.11.2021.p11932

\section{community capacity}

Based on the conclusions from the results of in-depth interviews and FGDs conducted with managers, community leaders and community beneficiaries, they are:

a. The management of the Kalulut Palace is able to develop networks outside the company's ring 1 such as Tanjung, Amuntai, Lampihong, and other villages around PT Adaro Indonesia's ring 1 through the KOMPAK community.

b. Development of knowledge and skills from the company to the managers of the Kalulut Palace in kalulut cultivation.

c. Development of knowledge and skills from managers to other cultivators with the openness of managers in teaching their knowledge and skills to other communities in terms of kalulut bee cultivation to the surrounding community and community.

a. The development of a good network in increasing knowledge and skills is carried out by the Kalulut Palace Manager by accepting people who want to learn how to cultivate Kalulut bees from the Kalimantan area and outside Kalimantan.

\section{a) PT Adaro Indonesia}

a. With the existence of the Kalulut Palace, the capacity obtained is that the manager has succeeded in being a resource person in every activity carried out by the provincial and national local governments in the field of developing kalulut honey.

b. With the honey kalulut istan, the manager is able to donate the best honey through independent research as an additional supplement for infectious and non-infectious diseases in addition to durability.

c. With the existence of kalulut honey, there is a development of the kalulut honey community in an effort to transfer skills and expertise in helping new programs related to kalulut honey

d. Management capabilities have increased, as can be seen from the increase in revenue and area of the Kalulut Palace's activities

\section{b) Department of Environment (DLH)}

The Balangan Regency Department of Environment (DLH) said that there was an increase in community capacity, especially for managers, families and management friends in terms of cultivating kalulut honey.

\section{c) Civil Social Organization}

\section{Manager}

The Istana Madu kalulut program increases the capacity of the surrounding community, after the program took place from 2018 there was an area expansion that duplicated the cultivation of kalulut honey. Although there are expansion problems in the Paringin Kota area, the management of the Madu Kalulut Palace is able to develop networks outside the region such as Tanjung, Amuntai, Lampihong, and other 
ISSN 2250-3153

villages around PT Adaro Indonesia ring 1 through the KOMPAK community.

\section{Community Leader}

Based on the results of in-depth interviews with community leaders in Paringin Kota Village, it was found that the Kalulut Honey Palace (Istana Madu Kalulut)program has not yet held training on how to cultivate kalulut bees around the area.

\section{Consumer}

The results of in-depth interviews from consumers of kalulut honey were found that the manager of the Madu Kalulut Palace was open in teaching their knowledge related to kalulut bee cultivation.

From the results of the Forum Group Discussion (FGD), the manager of the Madu Kalulut Palace accepted people who wanted to learn how to cultivate kalulut bees. Learning with him can come directly to the place or by telephone. There is no charge for training because he feels that the knowledge he has does not need to be sold. People who learn to cultivate kalulut bees are not only from the Kalimantan area, but also from outside Kalimantan. The manager of the Madu Kalulut Palace was once a speaker at an Islamic boarding school in a boarding school in Tanjung. He trained the administrators, students and female students on how to cultivate kalulut bees and gave them 15 kalulut bee hives. As a result, now they have succeeded in cultivating kalulut bees well.

\section{4) Programs can create new roles and relationships in social life}

Analyzed from the concept of primary stakeholders, in the CSR program of Istana Kalulut, which acts as primary stakeholders, are the Corporate Social Responsibility (CSR) Department of PT Adaro Indonesia, Land Management (LM) Department of PT Adaro Indonesia, and Quality, Health, Safety, Environment ( QHSE) Department of PT Adaro Indonesia. When analyzed from the concept of secondary stakeholders, it can be concluded that the secondary stakeholders in the Kalulut Palace are the Regional Government through the Forestry Service of Balangan Regency, Paringin Kota Village, community organizations and non-governmental organizations (NGOs) who are interested / active in the environmental sector in Balangan Regency. and the surrounding area.

Based on the conclusions from the results of in-depth interviews and FGDs conducted with managers, community leaders and community beneficiaries, they are:

1. Coordinate with the Environment Agency and the Regent of Balangan Regency to promote the potential of the local nature, in this case, Kalulut honey.

2. Communities in Balangan Regency and its surroundings join the Kalulut bee cultivator community in the KOMPAK (Komunitas Perlebahan Kalimantan/Kalimantan Beekeeping Community) forum.
3. The creation of new jobs in the Kalulut bee cultivation in the community, both in the Paringin area, Balangan Regency and outside other areas.

4. The formation of two Kalulut honey groups, namely the Kalulut Honey Community and KOMPAK (Komunitas Perlebahan Kalimantan/ Kalimantan Beekeeping Community).

\section{a) PT Adaro Indonesia}

The results of in-depth interviews from representatives of the private sector found that the existence of the Kalulut Palace could create a new community in social life

\section{b) Department of Environment (DLH)}

From the results of in-depth interviews with representatives of the Balangan Regency Government, it was found that the existence of the Kalulut Palace could create a new community in social life

\section{c) Civil Social Organization}

\section{Manager}

However, until this year the manager was able to coordinate with the Forestry Service and the Regent of Balangan Regency to promote the local natural potential and stand alone with independent funds from the profits obtained during the Honey Kalulut Palace program.

\section{Community Leader}

Based on the results of in-depth interviews from community leaders, it was found that there is a new role in society, namely the job of being a kalulut bee cultivator.

\section{Consumer}

Based on the results of in-depth interviews from consumers of the Kalulut Honey Palace, it was found that the Kalulut Honey Palace (Istana Madu Kalulut)program has a group that aims to cultivate Kalulut bees.

There are two groups of kalulut honey, namely the Madu Kalulut Community and KOMPAK (Komunitas Perlebahan Kalimantan/Kalimantan Beekeeping Community. The purpose of participating in these communities is to complement each other. If the honey stock in one group runs out, then another group can help increase the honey stock with the standard conditions must be as follows: from how to harvest it, etc. But at this time the manager of the Kalulut Honey Palace (Istana Madu Kalulut)has left the community because the purpose of the community is not clear. The point is that the Kalulut Honey Palace (Istana Madu Kalulut)manager hopes that when they join the community they can share information with each other regarding honey sad, but it's not really like that.

\section{5) Programs can develop community capacity}

Based on the conclusions from the results of in-depth interviews and FGDs conducted with managers, community leaders and community beneficiaries, they are: 
1. Development of community capacity by conducting lessons on kalulut bee cultivation directly or via telephone or online.

2. The manager is very open in sharing information with cultivators both in the Balangan area and from areas outside the Balangan Regency.

3. Cultivation training for the surrounding community so that the community can learn how to cultivate Kalulut bees.

4. Group members under the Kalulut Palace have the ability to harvest honey according to the standards from the Kalulut Palace with the assistance of groups of 5-6 people.

5. With the existence of the Kalulut Palace, the ability to manage kalulut honey has increased so that there are many variations of the output of kalulut honey, such as from taste, product appearance, distribution, promotion and packaging methods.

\section{a) PT Adaro Indonesia}

The results of in-depth interviews from representatives of the private sector were found and stated that the existence of the Kalulut Palace can improve and develop the community's capabilities

\section{b) Environment Service}

The results of in-depth interviews from representatives of the Balangan Regency Government found that the products from the Kalulut Palace were needed by the community because of their many benefits

\section{c) Civil Social Organization}

\section{Manager}

The honey kalulut palace program develops the capacity of the community in the ring 1 area of PT Adaro Indonesia and even outside areas such as North Kalimantan. The success of this program is to develop the community's capacity, namely through community networks. Although this program does not continue to run in the paringin city area, the success of the Pak Masuni group in managing the Kalulut Honey Palace (Istana Madu Kalulut)program has aroused the interest of people in other areas to develop kalulut honey cultivation. Managers as local heroes here play a very important role in developing community capabilities in the ring 1 area of PT Adaro. By conducting training either in person or via telephone/internet. One of the causes of other people's abilities to develop is hobbies, where people who are interested in developing this cultivation are people who already have an interest in honey livestock business

\section{Community Leader}

Based on the results of in-depth interviews obtained from community leaders in Paringin Kota Village, the Kalulut Honey Palace (Istana Madu Kalulut)Program has not yet held training related to how to cultivate kalulut bees because the socialization of the Kalulut Honey Palace (Istana Madu Kalulut)in the community is still lacking.

\section{Consumer}

From the results of in-depth interviews with consumers, it was found that with this program, groups under the Kalulut Honey Palace (Istana Madu Kalulut)have the ability to harvest honey according to the standards of the Kalulut Honey Palace, namely the quality of pure honey not mixed with other ingredients, honey extraction using a suction machine honey, and so on.

\section{d) Results of the Forum Group Discussion (FGD)}

The social change from the existence of the Kalulut Honey Palace (Istana Madu Kalulut)is that people who do not know how to cultivate kalulut honey, then come to the Kalulut Honey Palace (Istana Madu Kalulut)to learn how to cultivate, harvest honey, packaging, etc. Because of that then they started trying to cultivate each other. Usually, Madu Kalulut Palace accompanies groups of 5-6 people (less than 20 people).

\section{6) Programs can have a positive impact on the environment}

Based on the conclusions from the results of in-depth interviews and FGDs conducted with managers, community leaders and community beneficiaries, they are:

1. Increase public awareness by distributing plants to the surrounding community to be planted in the yard

2. Protecting the environment with the addition of plant species through planting for vegetation purposes

3. Improvement of forest conditions by reducing deforestation for the hunting of Kalulut honey.

4. Increase awareness of cultivators to carry out reforestation around the Kalulut cultivation area.

5. Using used pallets from the company for kalulut logs

\section{a) PT Adaro Indonesia}

The results of in-depth interviews from representatives of the private sector found that the existence of the Kalulut Palace was able to have a positive impact on the environment for the sustainability of the existing ecosystem.

\section{b) Department of Environment (DLH)}

The results of in-depth interviews from representatives of the Balangan Regency Government found that the existence of the Kalulut Palace had an impact on the environment around the Kalulut Palace

\section{c) Civil Social Organization}

\section{Manager}

Based on the results of an in-depth interview from the manager of the Kalulut Honey Palace, it was found that the existence of the Kalulut Honey Palace (Istana Madu Kalulut)can have a positive impact on the environment, namely the kalulut bees help pollinate plants so that plants 
ISSN 2250-3153

bear fruit more quickly.

\section{Community Leader}

Intensive honey bee cultivation in artificial nests, in addition to having a positive impact on increasing the production and quality of kalulut honey, also has an impact on reducing tree felling in the forest to search for kalulut honey. This can be seen from the pattern of the community in ring 1 of the Paringin Integrated Post-mining demonstration plot, which began cultivating kalulut honey. Mr. Maskuni UKM is a pioneer in the cultivation of kalulut honey by cultivating artificial nests.

\section{d) Results of the Forum Group Discussion (FGD)}

With the Kalulut Honey Palace, plants can be maintained and the environment is also maintained. There is no negative impact from the existence of the Kalulut Honey Palace, it's just that at first the Kalulut Honey Palace (Istana Madu Kalulut)cultivated 4 species of kalulut bees, but because cultivating it was rather difficult finally Kalulut Honey Palace (Istana Madu Kalulut)now cultivates 2 species of kalulut bees, namely the itama and torasika types.

\section{7) Programs can have a positive impact on the economy}

Based on the conclusions from the results of in-depth interviews and FGDs conducted with managers, community leaders and community beneficiaries, they are:

1. Helping the reseller economy with the difference in the selling price of IDR. 25,000 to IDR. 50,000/liter

2. Helping the economy of cultivators who learn from the Kalulut Honey Palace (Istana Madu Kalulut)

3. Increase profits for managers of Kalulut Honey Palace (Istana Madu Kalulut) products

4. Increase sales of nearby stalls through guest visits to Kalulut Honey Palace (Istana Madu Kalulut)

\section{a) PT Adaro Indonesia}

The results of in-depth interviews from representatives of the private sector found that with the existence of the Kalulut Palace the manager was able to meet primary, secondary, tertiary needs; provide an economic impact for the surrounding community with many guests who come to visit; increase revenue for resellers

\section{b) Department of Environment (DLH)}

The results of in-depth interviews from representatives of the Balangan Regency Government found that the existence of the Kalulut Palace had an economic impact on the community around the Kalulut Palace.

\section{c) Civil Social Organization}

\section{Manager}

Based on the results of an in-depth interview from the manager of the Kalulut Madu Palace, it was found that the existence of the Kalulut Madu Palace could increase income from the community's main occupations such as rice and rubber farmers. In fact, there are some people who give up their main job to resell products from the Madu Kalulut Palace (Istana Madu Kalulut) because their income is more profitable.

\section{Community Leader}

According to the results of in-depth interviews with community leaders in Paringin Kota Village, it was found that the economic impact on the surrounding community is still not visible because many people still do not know about the existence of the Palace.

\section{Consumer}

The results of in-depth interviews from consumers of the Madu Kalulut Palace (Istana Madu Kalulut) found that the existence of the Kalulut Madu Palace (Istana Madu Kalulut) could help the agent's economy.

\section{d) Results of the Forum Group Discussion ((FGD)}

There are resellers or people who resell products from Istana Madu Kalulut with a difference in the selling price of IDR. 25,000 to IDR. 50,000/liter. From the results obtained from reselling the Kalulut Honey Palace (Istana Madu Kalulut) products, it can help additional economies for resellers.

\section{8) Programs can have a positive impact on health}

Based on the conclusions from the results of in-depth interviews and FGDs conducted with managers, community leaders and community beneficiaries, they are:

1. Honey kalulut helps increase the body's immunity

2. Honey kalulut helps reduce the incidence of stroke

3. Honey kalulut helps reduce pain in the body such as uric acid, high blood pressure, high blood sugar levels/diabetes melitus, hepatitis B ulcers

4. Honey kalulut helps in reducing the risk of getting COVID-19

\section{a) PT Adaro Indonesia}

The results of in-depth interviews from representatives of the private sector found that consuming honey kalulut can reduce the risk of infectious and non-infectious diseases such as covid-19, hypertension, gout and others.

\section{b) Department of Environment (DLH)}

The results of in-depth interviews from representatives of the Balangan Regency Government found that the products from the Kalulut Palace were needed by the community because of their many benefits.

\section{c) Civil Social Organization}

\section{Manager}

Based on the results of an in-depth interview from the manager of the Kalulut Honey Palace, it was found that by drinking the products from the Kalulut Honey Palace, it could help cure the Covid 19 disease. 
ISSN 2250-3153

\section{Community Leader}

Based on the results of in-depth interviews from community leaders, it was found that if you drink honey, your body feels good and can help remove sweat from the body.

\section{Consumer}

The benefits of drinking honey kalulut is a reduction in the pain in the body such as uric acid and taken every night.

\section{d) Results of the Forum Group Discussion (FGD)}

The results of the Forum Group Discussion (FGD) found that drinking kalulut honey can also cure stroke. The benefits of drinking kalulut honey can also cure infections and are suitable for drinking during covid 19 to increase immunity

\section{9) The program can develop asset and human resource} (HR) development

Based on the conclusions from the results of in-depth interviews and FGDs conducted with managers, community leaders and community beneficiaries, they are:

1. There was an increase in assets in the form of human resources (HR) by employing local people to clean and help at the Kalulut Palace

2. Increased nest assets from 30 hives now to more than 300 hives/ log kalulut

3. Increasing assets by turning the Kalulut Palace into a Kalulut educational park in Balangan that can be visited by all levels of society

4. Formation of the Kalulut Balangan Community and KOMPAK

5. Increasing the number of plants as food ingredients is more suitable to support the improvement of the quality and quantity of Kalulut honey

\section{a) PT Adaro Indonesia}

The results of in-depth interviews from representatives of the private sector found that with the existence of the Kalulut Palace as a result of being able to buy land for the entrance to the location and the development of crystal herbs, the manager of the Kalulut Palace managed to become a resource person in every activity carried out by the government from regional to national. In addition, there is also the development of the honey kalulut community.

\section{b) Department of Environment (DLH)}

From the results of in-depth interviews with representatives of the Balangan Regency Government, it was found that the existence of the Kalulut Palace could preserve the type of bee.

\section{c) Civil Social Organization}

\section{Manager}

Based on the results of in-depth interviews from the management of the Kalulut Honey Palace, it was found that the initial formation of the Kalulut Honey Palace (Istana Madu Kalulut) had 30 kalulut bee hives, now the Kalulut Honey This publication is licensed under Creative Commons Attribution CC BY.
Palace (Istana Madu Kalulut) has 300 Kalulut bee hives with details of 260 Itama bees and 40 Torasica bees.

\section{Community Leader}

Based on the results of in-depth interviews from community leaders in the Paringin Kota Urban Village area, it was found that according to the Head of RT 14, the Madu Kalulut Palace Program (Istana Madu Kalulut) had not involved the surrounding community as workers.

\section{Consumer}

From the results of in-depth interviews with consumers of the Madu Kalulut Palace (Istana Madu Kalulut), it was found that during the formation of the Madu Kalulut Palace there were still no job openings to work at the Kalulut Madu Palace (Istana Madu Kalulut) because the workers at the Madu Kalulut Palace (Istana Madu Kalulut) were from their own managing families.

\section{d) Results of the Forum Group Discussion (FGD)}

The workers at the Madu Kalulut Palace are from their own family members and sometimes call people around to work such as cleaning and making houses for kalulut bee nests. Usually workers are given a salary of 100 thousand / day.

\section{0) Program Continuity}

Based on the conclusions from the results of in-depth interviews and FGDs conducted with managers, community leaders and community beneficiaries, they are:

a. The existing cultivators must be independent, develop their wings, so that they can form industries, open markets and an area or center for Kalulut Honey

b. Adding halal and BPOM labels to make it easier to market

c. Expanding the network of kalulut beekeeping groups

d. There is quality control to check the quality of kalulut honey so that the quality is maintained

e. Kalulut Palace can be used as a tourist attraction in Paringin Kota Village

f. The sales of kalulut honey will be further increased by expanding the network

g. Increasing promotions and results from the Kalulut Palace (Istana Kalulut) can be used as souvenirs Increasing the number of plants in increasing the quality and quantity of kalulut honey

h. With the presence of kalulut honey, it is able to carry out further development besides the development of crystal guava behind the program

i. With the existence of the Kalulut Palace (Istana Kalulut), the capacity obtained is that the manager has succeeded in being a resource person in every activity carried out by the provincial and national local governments in the field of developing kalulut honey.

j. With the existence of kalulut honey, there is a development of the kalulut honey community in an effort 
to transfer skills and expertise in helping new programs related to kalulut honey

k. As a research and development facility for the Kalulut Palace (Istana Kalulut), QHSE (Quality Health Safe Environment) has been carried out for the post-mining area in the Paringin area by using artificial wood as a substitute for real wood.

1. With the existence of the Kalulut Palace (Istana Kalulut), the community's needs for self-development have increased by developing varieties of flower plants that are food for kalulut bees

\section{a) PT Adaro Indonesia}

The results of in-depth interviews with the private sector that the presence of kalulut honey can help develop other programs, capacity building for managers and communities and community development and plant varieties development.

\section{b) Department of Environment (DLH)}

The results of an in-depth interview from the Head of the Department of Environment (DLH), he hopes that the management who has now cultivated to be independent, can develop wings and collaborate with related agencies so that the Kalulut Honey Palace (Istana Madu Kalulut) can become an industry, and become an area or center of Kalulut honey.

\section{c) Civil Social Organization}

\section{Manager}

Based on the results of an in-depth interview from the manager of the Kalulut Honey Palace (Istana Madu Kalulut), he hopes that the vegetation can increase from before, for human resources to explore its potential so that they can be better at cultivating kalulut bees, and keep the purity of honey so that the quality of honey is maintained.

\section{Community Leader}

The results of in-depth interviews from community leaders in the Paringin Kota Village, it is hoped that the products from the Madu Kalulut Palace (Istana Madu Kalulut) can be promoted through advertisements on social media because nowadays digitalization has been implemented so that the products from the Kalulut Madu Palace (Istana Madu Kalulut) can be even more advanced.

\section{Consumer}

The results of in-depth interviews from consumers of the Madu Kalulut Palace, it is hoped that the Kalulut Honey Palace (Istana Madu Kalulut) can carry out wider socialization related to training in kalulut bee cultivation and the products produced so that people are more familiar with the Kalulut Honey Palace (Istana Madu Kalulut) and it is hoped that with open training on how to cultivate kalulut bees, many people in the Paringin Village area Cities can participate in cultivating too.

\section{d) Results of the Forum Group Discussion (FGD)}

From the results of the Forum Group Discussion (FGD), the sustainability of this program is expected to be used as a tourism object in the Paringin City Village.

\section{CONCLUSION}

The Kalulut Palace (Istana Kalulut) Program which is the company's Social Innovation Program has been developed based on environmental and social issues and based on community needs that are able to synergize with sustainable development and play a role in disasters, increase community capacities and capabilities, new roles and relationships in social life and develop assets and resources. local people. Based on the calculation of the SROI ratio, it is known that for every 1 Rupiah invested in the Kalulut Honey Palace (Istana Madu Kalulut) program, there will be a social return on investment of 30.34 Rupiah. This ratio is classified as high or very promising in the world of impact investment.

The payback period is quite short where for an investment of this size it will take only 1.9 months before an equivalent value of the investment is realized IDR 524.935.000.

\section{REFERENCES}

Abdurahman A, Ghalib S dan Maryono M. 2020. Analisis Lingkungan Bisnis PT Adaro Energy, Tbk. Jurnal Bisnis dan Pembangunan, 9(1), pp.1-19.

Gray RH. 1990. Corporate Social Reporting by UK Companies: A Cross-Sectional and Longitudinal Study an Interim Report. Draft/Working Paper.

Gray, Rob, Reza K. and Simon L. 1993. Social and Environmental Reporting by UK Companies: A Longitudinal Study. A Tale of Two Samples. The Construction of a Research Database and An Exploration of the Political Economy Thesis, Unpublished paper.

Guthrie J dan LD Parker. 1990. Corporate Social Disclosure Practice: A Comparative International Analysis, Advances in Public Interest Accounting, Vol. 3, pp. 159175

Hutapea EC, Poernomoputri TP and Sihombing P. 2013. Analisis Valuasi Nilai Wajar Saham PT. Adaro Energy Tbk Menggunakan Metode Free-cash Flow to Firm (Fcff). Journal of Applied Finance \& Accounting, 5(2), pp.240-270.

Kiptia AN. 2017. Studi Identifikasi Program Campus Social Responsibility (CSR) Institut Teknologi Sepuluh Nopember (ITS) untuk meningkatkan Value ITS dan masyarakat sekitar (Doctoral dissertation, Institut Teknologi Sepuluh Nopember).

Kiroyan N. 2006. Good Corporate Governance (GCG) dan Corporate Social Responsibility (CSR) Adakah Kaitan di Antara Keduanya?", Economics Business Accounting Review, Edisi III, SeptemberDesember 2006, Hal. 4558.

Nurhayati T, Rosilawati Y dan Ishak A. 2020. Community development "Istana Kelulut" Masyarakat pasca tambang sebagai aktualisasi Corporate Social 
Responsibility (CSR) PT Adaro Indonesia. Jurnal Audience: Jurnal Ilmu Komunikasi, 3(2), pp.147-169.

Pang YH. 1982. Financial Reporting: Disclosures of Corporate Social Responsibility.

Rusdin. 2016 Corporate Social Responsibility (CSR) Disclosure and the Implications of Earning Response Coefficient (ERC). Jurnal AdBispreneur. Vol. 1 No. 2 Agustus 2016. Hlm. 153-164.

Sayekti Y. 2006. Determinan Pengungkapan Informasi Corporate Social Responsibility (CSR) dalam Laporan Tahunan Perusahaan (Suatu Usulan Studi Empiris pada Perusahaan yang Terdaftar di Bursa Efek Jakarta), Tugas Mata Kuliah Seminar Doktoral Akuntansi Keuangan, Tidak Dipublikasikan, Program Pascasarjana Ilmu Akuntansi, FEUI.

Soendjoto MA, Riefani MK, Triwibowo D dan Wahyudi F. 2016. Jenis burung di area reklamasi PT Adaro Indonesia yang direvegetasi tahun 1996/1997. Proceeding Biology Education Conference, 13(1), 723729.

Soendjoto MA, Riefani MK, Triwibowo D dan Wahyudi F. 2015. Avifauna di Area Reklamasi PT Adaro Indonesia.

SROI Network UK, 2012. A guide to Social Return on Investment.

Triwibowo D. 2021. Pengembangan Madu Kelulut Paringin, Kab. Balangan: Integrasi Program Pascatambang Batubara dan Pemberdayaan Masyarakat. PRIMA: Journal of Community Empowering and Services, 5(1), pp.91-101. 